\title{
Variability of taurine concentrations in Mytilus galloprovincialis as a function of body size and specific tissue
}

\author{
José MF Babarro* and María José Fernández Reiriz
}

\author{
Instituto de Investigaciones Marinas CSIC, Eduardo Cabello 6, 36208 Vigo, Spain \\ *Corresponding author. Email: jbabarro@iim.csic.es \\ Tel.: +34 986231930 Ext. 207; Fax: +34 986292762
}

\begin{abstract}
Variability of the free amino acid taurine (2-aminoethane sulfonic acid) was studied according to increasing size of the mussel Mytilus galloprovincialis and its tissue-specificity. Isometric and/or allometric relationships were established for the different tissue's weights with regard to total soft mass values of the mussels within an experimental range of 20-60 $\mathrm{mm}$ shell length. Relative amount of taurine dropped significantly with increasing size of mussels (whole soft tissues) according to allometric function with a slope value of approx. 0.155. Furthermore, the latter inverse relationship between taurine and increasing size was specifically confirmed for gill epithelium and labial palps tissues. Relative amounts of taurine in digestive gland, mantle and foot remained unchanged with increasing size of mussels. Weight values of those tissues in which relative taurine concentrations significantly dropped (gill epithelium and labial palps) or increased (pam) with increasing size of individuals were characterised by isometric relationships with the total soft mass (TSM) values (slope approx. 1) and therefore, represented similar percentage values regardless increasing size of individuals i.e. 16\% (gill epithelium), 1.9\% (labial palp) and 8.4\% (pam) of TSM. The increment in the area of the epithelium together with the most likely functionality of the sulphur-containing amino acid taurine in the production of sulphonated mucopolysaccharides associated to both mucus-producers gill epithelium and labial palps are suggested to be the cause of the relative taurine drop with increasing size of the mussels. Differences between experimental slopes obtained here for the relative taurine content of gill epithelium vs. total soft mass relationship and the theoretical values for the scaling of gill area and weight values i.e. -0.33 are discussed.
\end{abstract}


Keywords: Mytilus galloprovincialis, taurine, increasing size, tissue analysis, gill epithelium

\section{Introduction}

Taurine (2-aminoethane sulfonic acid) is synthesized from methionine via cystine by a series of enzymatic reactions and has been reported to be present in trace quantities in seawater (Allen and Garret 1972), although represents high amounts in marine animals and only small quantities (if any) in freshwater animals. The latter fact evokes its functionality in the osmorregulation processes of individuals (Zurburg and de Zwaan 1981). All of the demonstrated taurine synthesis pathways in invertebrate tissues incorporate cysteine (Bishop et al. 1983; Huxtable 1992), and intertidal molluscs were described to utilise external cysteine sources to maintain taurine pools (Allen and Garret 1972). Taurine represents in many animals one of the most abundant of the low-molecular-weight organic constituents and specifically in euryhaline bivalves, its quantity being a direct function of the environmental salinity (Bishop et al. 1983).

When the latter main functionality of taurine in osmorregulation is expected to govern all, it might also be expected a direct relationship between taurine and the amount of tissue. Nowadays, it is clear that osmotic function is not the only action of taurine. Some other reported functions/uses of the amino acid taurine refer to it as end product of ammonia assimilation processes in environments with high presence of the former toxic product (Lee et al. 1997), as part of sulfur cycle and important sulfide storage compounds allowing to maintain low levels of intracellular sulfide (Joyner et al. 2003), as a component involved in cellular $\mathrm{Ca}^{+2}$ regulation (Zachariassen et al. 1996) and detoxification processes i.e. methalloproteins through the significance of its precursors methionine and cysteine (Jakoby and Griffiths 1987), as growth indicator (Conceição et al. 1997; Kim et al. 2005) as well as many other metabolic and non-metabolic actions (see extensive review of Huxtable 1992).

First report of an inverse relationship between relative taurine amount and bivalve's body size was done by Allen and Garret (1972) with whole soft tissues of Mya arenaria. The latter authors had hypothesized that taurine, as an intermediate in sulphur amino-acid metabolism, could be linked to the formation of sulphonated mucopolysaccharides providing sulphur content of the mucus that is so essential to bivalve's function. Indeed, mucus in marine invertebrates contains high levels of sulphate anion (Powell et al. 1982) and represents an important component in both gill and labial palps epithelia of bivalves (Allen and Garrett 1972) because many functions in the latter tissues depend upon a copious supply of 
sulphonated polysaccharides (Livingstone 1985). Specifically, gill represented the primary

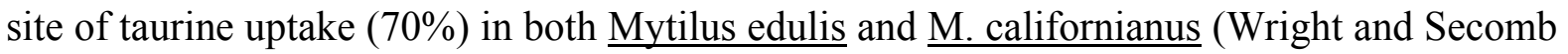
1984) and its epidermal transport is involved in the maintenance of high concentrations.

In the present study, we have performed a new approximation to the taurine variability and most likely functionality with increasing body size of the mussel Mytilus galloprovincialis. The hypothesis of a taurine drop with increasing size of individuals as a consequence of the increment in the area of the epithelium and consequently, needs of the latter sulfur-containing metabolite during growth and not linked to the volume of the tissues will be tested. For that, a specific analysis of taurine concentrations in different tissues-organs of the mussel $\underline{\mathrm{M}}$. galloprovincialis i.e. gill epithelium and labial palps as well known mucus-producer tissues but also mantle, digestive gland, foot and posterior adductor muscle (pam) will be carried out.

\section{Material and Methods}

\subsection{Individuals}

Intertidal individuals of Mytilus galloprovincialis were sampled in the littoral coastline near the laboratory (Ría de Vigo NW Spain). A body size range of approx. 20-60 mm shell length was considered. Individuals were immediately transported to the laboratory and three subgroups were established $(n=3)$. From each subgroup, two replicates of a number of mussels (5-15 individuals), according to the experimental body size range (20-60 $\mathrm{mm}$ ) were sampled for each shell length class i.e. $10 \mathrm{~mm}$. One replicate was sampled for collection of the whole soft tissues and individuals of the other replicates, were individually and carefully dissected for collection of the different soft tissues gill epithelium, labial palps, posterior adductor muscle, digestive gland, foot and mantle. All tissues collected (whole and specific soft tissues) were frozen at $-80^{\circ} \mathrm{C}$ for few days and lyophilised for 48 hours (Virtis Bench Top 3 Model).

All shell valves from each shell length class were weighted and together with soft tissues weight obtained from both replicates i.e. whole tissues and sum of specific tissues dissected after freeze-drying (see before), were considered to obtain condition index values (CI). CI of the experimental mussels was obtained according to Freeman (1974) and the formula: $\mathrm{CI}=\left(\mathrm{DW}_{\text {tissue }} / \mathrm{DW}_{\text {shell }}\right) \times 100$, where $\mathrm{DW}_{\text {tissue }}$ corresponds to dry weight of whole soft tissues and $\mathrm{DW}_{\text {shell }}$ to dry weight of the shell. CI remained rather similar through the increasing size of the mussels with values of $6.11 \% \pm 0.29$. 


\subsection{Taurine measurements}

The extracts for HPLC analyses were prepared from lyophilised tissues for $48 \mathrm{~h}$ (see before). Dry whole and specific soft tissues were then powdered and weighted. Briefly, approx. 100 $\mathrm{mg}$ of both whole and specific soft tissues was suspended in $5 \mathrm{ml} 0.2 \mathrm{M}$ perchloric acid. The mixture was homogenised in an Ultra Turrax blender for 2 min and kept in an ultrasonic bath for $30 \mathrm{~min}$ and then centrifuged at $10000 \mathrm{~g}$ for $20 \mathrm{~min}$. The supernatant was filtered through a $0.45 \mu \mathrm{m}$ membrane. Determination of taurine was performed by reverse-phase highperformance liquid chromatography of its dabsyl derivative. Taurine standard and dabsyl chloride were purchased from Sigma. Free amino acid separation method consisted in a slight modification of that reported by Krause et al. (1995). The chromatograph was a Waters Alliance HPLC System with a 2690 separations module and a Waters 996 photodiode array detector (440-480 nm). The stationary phase was a $C_{18}$ column (Waters Symmetry, 150 x 4.6 $\mathrm{mm}, 3.5 \mu \mathrm{m}$ particle size, $100 \AA$ pore size) thermostated at $50^{\circ} \mathrm{C}$ either by means of the Allience System column oven. Twenty $\mu 1$ of the derivatized samples were injected. Dabsylated amino acids were eluted at a flow-rate of $1 \mathrm{ml} / \mathrm{min}$ using a gradient made with phase A $(9 \mathrm{mM}$ sodium dihydrogenphosphate. $4 \%$ dimethylformamide and 0.1 $0.2 \%$ triethylamine titrated to $\mathrm{pH} 6.55$ with phosphoric acid) and $\mathrm{B}$ (80\% aqueous acetonitrilo) with a gradient profile that corresponds to that used by Pinho et al. (2001). For quantification, nor-leucine was used as internal standard.

\subsection{Gill surface area analysis}

Micro-measurements of the gill structure (holobranch) were performed on a number of mussels from the experimental population, covering the whole body size range of $20-60 \mathrm{~mm}$ shell length. Gill tissues were immediately and carefully dissected at arrival in the laboratory by using micro-forceps and separating the membrane that joint the latter tissue to the rest of soft body in one valve (demibranch). Edge of mantle was also removed. Each demibranch from one valve were placed on a glass microscope slide, parallel to the camera lens and gently extended with the micro-forceps. Manipulation of the demibranch was carried out at minimum possible to avoid disturbance and degradation.

Digital images of each demibranch that includes two lamellae were recorded and image analysis (IA) was performed using the software QWin (C Leica Imaging Systems) on a PC (AMD Athlon XP 3000+) connected to a video camera (Leica IC A) on a stereo microscope 
(Leica MZ6). Camera and light settings were established at the beginning of the analysis and kept constant throughout the whole procedure. For that, two pictures of each demibrach were obtained: one from above and the other one obliquely following Scott (2005). From the above picture, apical surface area values of each demibranch (in $\mathrm{mm}^{2}$ ) were obtained by drawing the exact contour of the extended demibranch (IA). Number of filaments per millimetre of demibranch was also measured from the above picture after calibrating with a ruler incorporated to the glass slides next to the demibranch (Nikon D1x: 23.7 x $15.6 \mathrm{~mm}$ RGB CCD; 3008 x 1960 recording pixels). From the oblique picture, thickness (mm) of a single lamella (two lamellae from each demibranch) was obtained following the same calibration method described before $(\mathrm{mm})$ and establishing a mean value along the $\mathrm{X}$-axis of the demibrach. Apparent gill area (GA apparent) for each lamella was obtained by multiplying the number of filaments and the mean thickness measured from oblique view. Gill area was then obtained by the product of GA apparent and the apical surface value $\left(\mathrm{mm}^{2}\right)$ measured from the above picture and multiplied by a factor of 8 to obtain total area of the gill structure (holobranch).

\subsection{Statistical analysis}

Taurine values in all cases were fitted to allometric models according to the function $Y=a \cdot X^{b}$ where $\mathrm{Y}$ is taurine in $\mu$ moles per gram of dry soft tissues (whole and specific tissues), $\mathrm{X}$ is total soft mass values per individual and, a and b represent intercept and slope parameters, respectively. Isometric and allometric relationships between different tissue's soft weight and experimental increasing size were established according to Student's t-tests by comparing the experimental slopes of the logarithmic transformed regressions with specific value i.e. 1 for isometry (Zar 1999).

Concentrations of the free amino acid taurine are presented as $\mu \mathrm{mol}$ per gram dry weight of specific tissue and each replicate represent a pool of 5-15 individuals according to their size (see before). For all analyses performed a statistical computer package STATISTICA 6.0 was used. 


\section{Results}

\section{$\underline{\text { 3.1. Taurine vs. increasing size of individuals }}$}

Figure 1 illustrates the inverse relationship obtained for the relative amount of taurine in whole soft tissues of mussels with regard to increasing size. Taurine variability with size was fitted to an allometric function following the model: taurine $=$ a.size ${ }^{\mathrm{b}}$ (see Material and Methods) where the values obtained for the intercept (a) and slope (b) were 282.25 \pm 27.20 and $-0.1547 \pm 0.013$, respectively.

\subsection{Tissue analysis (I): specific tissue weight vs. total soft weight relationships}

Relationships between specific tissue weights and increasing size of the mussels are presented in Figure 2 and 3. Isometry was obtained for the specific tissue's weight of gill epithelium, labial palps and posterior adductor muscle (pam) with regard to total soft tissues of individuals (TST) and according to the following power functions:

(A) Gill epithelium (mg/ind) $=0.1596 \mathrm{TST}^{1.0007 \pm 0.035} \mathrm{n}=15 \mathrm{r}^{2}=0.997 \mathrm{P}<0.001$

(B) Labial palps (mg/ind) $=0.0067 \mathrm{TST}^{1.1703 \pm 0.082} \mathrm{n}=15 \mathrm{r}^{2}=0.942 \mathrm{P}<0.001$

(C) PAM (mg/ind) $=0.1018$ TST $^{0.9616 \pm 0.024} \mathrm{n}=15 \mathrm{r}^{2}=0.992 \mathrm{P}<0.001$

Values of the slope reported for the latter relationships were not significantly different from unity i.e. isometry (Student's t-Test; $\mathrm{P}>0.05$ ) and this result caused that relative percentages of the tissues remained unchanged within body size range of individuals with values of $16.2 \% \pm 0.92,8.4 \% \pm 0.76$ and $1.9 \% \pm 0.6$ for gill epithelium, pam and labial palps, respectively (Figure 2D).

On the contrary, allometric functions were established for weight values of digestive gland, foot and mantle tissues with regard to increasing size of individuals (Figure 3) with values of the slope that were significantly different of 1 according to t-test performed (Figure 3 A-C; $0.01>\mathrm{P}<0.001 ;$ Student's t-Test):

(A) Digestive gland (mg/ind) $=0.3175 \mathrm{TST}^{0.9153 \pm 0.022} \mathrm{n}=15 \mathrm{r}^{2}=0.992 \mathrm{P}<0.001$

(B) Foot (mg/ind) $=0.0658 \mathrm{TST}^{0.8626 \pm 0.023} \mathrm{n}=15 \mathrm{r}^{2}=0.991 \mathrm{P}<0.001$

(C) Mantle (mg/ind $)=0.3965 \operatorname{TST}^{1.0533 \pm 0.014} \mathrm{n}=15 \mathrm{r}^{2}=0.998 \mathrm{P}<0.001$

Consequently, a significantly drop was observed for the relative weight percentages that digestive gland and foot tissues represented with increasing size of individuals whereas a significant increase was observed for the mantle tissues (Figure 3D). 


\subsection{Tissue analysis (II): taurine concentrations with increasing size}

Figure 4 illustrates the relative concentrations of the free amino acid taurine in different tissues-organs of the mussels as well as its variability with increasing size of individuals associated to each tissue. Taurine variability with size of individuals was fitted to allometric models (see Material and Methods) and relationships are also drawn in Figure 4. Gill epithelium and labial palps represented the only tissues in which an inverse relationship between relative amounts of taurine as $\mu$ moles per unit of weight (gram of tissue) and increasing size of individuals was observed (Figure 4 A-B). The latter relationships could be modelled according to the following allometric functions:

Gill: $\quad$ Taurine $\left(\mu\right.$ moles g gill $\left.{ }^{-1}\right)=498.27 \mathrm{TST}^{-0.159 \pm 0.017} ; \mathrm{r}^{2}=0.917 ; \mathrm{n}=15 ; \mathrm{P}<0.001$

Labial palps: Taurine ( $\mu$ moles g labial palp $\left.{ }^{-1}\right)=577.84$ TST $^{-0.101 \pm 0.030} ; \mathrm{r}^{2}=0.516 ; n=15$; $\mathrm{P}<0.01$

Taurine concentrations in mantle, digestive gland and foot did not show any significant pattern with increasing size of individuals (Figure 4 D-E-F; $P>0.05$ ), which in turn caused that taurine represented similar mean values of $163.66 \pm 20.33,196.10 \pm 23.60$ and 309.32 $\pm 37.54 \mu$ moles per gram of mantle, gland and foot, respectively and regardless the increasing size of mussels. Contrarily to the latter observations in gill epithelium and labial palps (see before), relative taurine concentrations in pam tissue increased significantly with size of individuals following the allometric function: Taurine $\left(\mu\right.$ moles $\left.\mathrm{g} \mathrm{pam}^{-1}\right)=109.99 \mathrm{TST}$ ${ }^{0.116 \pm 0.035} ; \mathrm{r}^{2}=0.643 ; \mathrm{n}=15 ; \mathrm{P}<0.01$ (Figure 4C).

\section{Discussion}

Growth of bivalves represents an increase in their mass (volume) and therefore, an increment in their individual taurine content to maintain osmotic balance should be expected (Welborn and Manahan 1995) as a consequence of its main functionality (see Introduction). Adult bivalves have been observed to present rather slow rates of taurine synthesis, at least insufficient to explain the high amounts encountered in their tissues (Bishop et al. 1983) which in turn has suggested that individuals must acquire taurine per se from dietary sources (Hosoi et al. 2003).

A drop in taurine amounts with increasing size of bivalves had been observed by Allen and Garret (1972) in whole tissues of Mya arenaria at first and is corroborated in the present 
survey for whole tissues of Mytilus galloprovincialis (Figure 1). Specific tissue analysis in the present survey extended our knowledge by confirming that such inverse relationship between relative amounts of taurine and increasing size of mussels is associated to both gill epithelium and labial palps, with especial importance for the former tissue as consequence of its relative weight values in the total soft mass (16.2\%; Figure 2D). First of all, it is important to note that considering the allometric functions reported for gill epithelium, labial palps and pam as well as the mean values of taurine amounts for increasing weight of mantle, digestive gland and foot tissues (Figure 4), the highest amounts of taurine were observed in gill epithelium (A), labial palps (B) and foot (F) as compared to lower values in pam (C), mantle (D) and digestive gland (E). These results are in agreement with the study of Zurburg and De Zwaan (1981) that reported a higher relative contribution of taurine in gill (70\%) and foot $(60 \%)$ with regard to lower relative percentages in pam, mantle or hemolymph that represented values of $40 \%$.

Both gill epithelium and labial palps are known to produce the most mucus in molluscs (Allen and Garret 1972) as consequence of its main functionality in particle processing and feeding strategies (Beninger et al. 1993). Mucus of marine invertebrates contains high levels of sulphate anion and an increase in the latter sulphate needs is accompanied by an increase of the taurine precursor cystic acid levels (Lee et al. 2004). Powell et al. (1982) have observed the latter significant relationship between taurine amounts and its precursor cystic acid in Crassostrea virginica subjected to high turbidity values, which in turn caused an increase in mucus secretion. It is important to note here that actions by which taurine pool may be enlarge or shorten in the gill structure might be represented by differences in osmolarity once assuming volume regulation as main concern for taurine. In the present survey, however, the latter factor cannot be considered as significant enough to explain variability reported here due to the fact that experimental mussel population is selected from the same intertidal location and subjected to similar environmental variability during their growth patterns. The fact that relative taurine drop was specifically observed here in gill and labial palps, would support the hypothesis that the sulphur-containing free amino acid taurine represents great importance in the metabolism of sulfur as substrate in mucopolysaccharides production of the latter epithelia which in turn would increase its quantitative importance with increasing size of individuals.

Remarkably, relative amounts of taurine did not present any significant variation with increasing size of the mussels considering mantle, digestive gland and foot tissues (Figure 4). 
Only in posterior adductor muscle, an allometric increase of relative taurine amounts with size of mussels, contrarily to gill epithelium and labial palps, was observed (Figure 4C). In this way, significant changes in taurine amounts with increasing size of the mussels were significant in those tissues in which proportions did not vary with increasing size i.e. remained isometric with body size (Figure 2D). Although relative taurine drop in gill and labial palps is suggested here to be linked to mucus-producer epithelia in association with size of the mussels (see before), the reported relative increase of taurine in pam tissue with increasing size of individuals cannot be completely addressed here with our data. Taurine is present in a high-energy gradient in the posterior adductor muscle (Zachariassen et al. 1996) and may present great responsibility in volume-regulatory response of this tissue but also in many other functions (see Introduction) for which the increasing size factor's influence are not completely well-understood.

Gill area is expected to scale with (weight) ${ }^{0.67}$ of individuals (Jones et al. 1992), and that was supported by several studies with Mytilus edulis that observed allometric exponent of $2 / 3$ for the latter relationship (Vahl 1973; Møhlenberg \& Riisgård 1979; Meyhöfer 1985). The latter relationships meant that gill area per unit of weight is expected to scale with (weight) ${ }^{-1 / 3}$ (Jones et al. 1992). When we hypothesize here that the free amino acid taurine would be a significant metabolite in the sulphur metabolism linked to mucopolysacharides formation in gill epithelium, one might have expected similar allometric relationship for the taurine amount per unit of gill weight as compared to the theoretical one i.e. $-1 / 3$ since mucus would be distributed along the whole gill structure. However, allometric slopes obtained here were significantly different either in whole tissues of the mussel M. galloprovincialis (Figure 1) or its gill epithelium (Figure 4). In order to approach the latter gape, preliminary analysis of the gill surface area considering micro-measurements by digital image analysis of the above and oblique view (see Material and Methods; Scott 2005) helped us to consider that slope values of the gill surface area vs. size of mussels (weight) would be rather different than theoretical ones (Figure 5). The latter relationship gill area vs. whole soft mass values for the intertidal M. galloprovincialis gave significantly higher slopes up to approx. 0.85 (Figure 5) which in turn would fit well with experimental allometric function observed here for taurine per unit of gill weight vs. increasing size (-0.16). This result needs more extended research to confirm such slope values but introduce new insights to explain other functionalities of specific organic compounds i.e. taurine within certain tissues of mussels in which are expected to play other significant roles than those already reported. 
As a summary, it can be said that the sulfur-containing free amino acid taurine is confirmed to represent an inverse relationship with increasing size of the mussel Mytilus galloprovincialis. This was demonstrated for the whole soft tissues of individuals and, furthermore, linked to specific tissues gill epithelium and labial palps that represented $16.2 \%$ and $1.9 \%$ relative weight percentage values, respectively regardless experimental body size and would suggest participation of taurine in processes commonly involved in these epithelia i.e. secretion of mucopolisaccharides with significant needs of sulphate anion.

\section{Acknowledgements}

We would like to thank R. Filgueira, L. Peteiro, B. González and L. Nieto for technical assistance with collection and treatment of the mussels.

\section{References}

Allen, J.A., and Garret, M.R., 1972. Studies on taurine in the euryhaline bivalve Mya arenaria. Comp. Biochem. Physiol. 41A, 307-317.

Beninger, P.G., St-Jean, S., Poussart, Y., and Ward, J.E., 1993. Gill function and mucocyte distribution in Placopecten magellanicus and Mytilus edulis (Mollusca: Bivalvia): the role of mucus in particle transport. Mar. Ecol. Progr. Ser. 98, 275-282.

Bishop, S.H., Ellis, L.L., and Burcham, J.M., 1983. Amino acid metabolism in molluscs. Pp. 243-327. In The Mollusca: Metabolic Biochemistry and Molecular Biomechanics. PW Hochachka, ed. Academic Press, New York.

Conceição, L.E.C., van der Meeren, T., Verreth J.A.J., Vejen M.S., Houlihan, D.F., and Fyhn, H.J., 1997. Amino acid metabolism and protein turnover in larval turbot (Scophthalmus maximus) fed natural zooplankton or Artemia. Mar. Biol. 129, 255-265.

De Vooys, C.G.N., 1991. Anaerobic metabolism in sublittoral living Mytilus galloprovincialis in the Mediterranean.IV. Role of amino acids in adaptation to low salinities during anaerobiosis and aerobiosis. Comp. Biochem. Physiol. 100A, 423-431.

Freeman, K.R., 1974. Growth, mortality and seasonal cycle of Mytilus edulis in two Nova Scotian embayments. Department of the environment, Fisheries and Marine Service, Canada, Technical Report No. 500, p. 112.

Hosoi, M., Kubota, S., Toyohara, M., Toyohara, H., and Hayashi, I., 2003. Effect of salinity change on free amino acid content in Pacific oyster. Fish. Sci. 69, 395-340.

Huxtable, R.J., 1992. Physiological actions of taurine. Physiological reviews 72 (1), 101-163. 
Jakoby, W.B., and Griffiths, O.W., 1987. Sulfur and sulfur amino acids. Methods in Enzymology. Vol. 143. Academic Press, Inc. Orlando, p. 582.

Jones, H.D., Owen, G.R., and Southern T.A., 1992. Gill dimensions, water pumping rate and body size in the mussel Mytilus edulis L. J. Exp. Mar. Biol. Ecol. 155, 213-237.

Joyner, J.L., Peyer, S.M., and Lee, R.W., 2003. Possible roles of sulfur-containing amino acids in a chemoautotrophic bacterium-Mollusc Symbiosis. Biol. Bull. 205, 331-338.

Kim, S.K., Takeuchi, T., Yokoyama, M., Murata, Y., Kaneniwa, M., and Sakakura, Y., 2005. Effect of dietary taurine levels on growth and feeding behavior of juvenile Japanese flounder Paralichthys olivaceus. Aquaculture 250 (3-4), 765-774.

Krause, I., Bockhardt, A., Neckermann, H., Henle, T., and Klostermeyer, H., 1995. Simultaneous determination of amino acids and biogenic amines by reverse-phase highperformance liquid chromatography of the dabsyl derivatives. J. Chromatogr. A, 715, 6779.

Lee, R., Childress, J., and Desaulniers, N., 1997. The effects of exposure to ammonia on ammonia and taurine pools of the symbiotic clam. J. Exp. Biol. 200 (21), 2797-2805.

Lee, N.H., Han, K.N., and Choi, K.S., 2004. Effects of salinity and turbidity on the free amino acid composition in gill tissue of the Pacific oyster, Crassostrea gigas. J. Shellfish Res. 23 (1), 129-133.

Livingstone, D.R., 1985. Biochemical measurements. In: Bayne, B.L., Brown, D.A., Burns, K., Dixon, D.R., Ivanovici, A., Livingstone, D.R., Lowe, D.M., Moore, M.N., Stebbing, A.R.D., and Widdows, J., (Eds.). The effects of stress and pollution on marine animals pp. 81-132, Praeger, New York.

Meyhöfer, E., 1985. Comparative pumping rates in suspension-feeding bivalves. Mar. Biol. $85,137-142$.

Møhlenberg, F. and Riisgård, H.U., 1979. Filtration rate, using a new indirect technique, in thirteen species of suspension-feeding bivalves. Mar. Biol. 54, 143-148.

Pinho, O., Ferreira, I.M.P.L.V.O., Mendes, E., Oliveira, B.M., Ferreira, M., 2001. Effect of temperature on evolution of free amino acid and biogenic amine contents during storage of Azeitão cheese. Food Chem. 75, 287-291.

Powell, E.N., Kasschau, M., Chen, E., Koenig, M., Pecon, J., 1982. Changes in the free amino acid pool during environmental stress in the gill tissue of the oyster, Crassostrea virginica. Comp. Biochem. Physiol. 71A (4), 591-598.

Scott, K.M., 2005. Allometry of gill weights, gill surface areas, and foot biomass $\delta^{13} \mathrm{C}$ values of the chemoautotroph-bivalve symbiosis Solemya velum. Mar. Biol. 147, 935-941. 
Vahl, O., 1973. Pumping and oxygen consumption rates of Mytilus edulis L. of different sizes. Ophelia 12, 45-52.

Welborn, J.R., and Manahan, D.T., 1995. Taurine metabolism in larvae of marine molluscs (Bivalvia, Gatropoda). J. Exp. Biol. 198, 1791-1799.

Wright, S.H., and Secomb, T.W., 1984. Epidermal taurine transport in marine mussels. Am. J. Physiol. Regul. Integr. Comp. Physiol. 247, 346-355.

Zachariasen, K.E., Olsen, A.J., and Aunaas, T., 1996. The effect of formaldehyde exposure on the transmembrane distribution of free amino acids in muscle of Mytilus edulis. J. Exp. Biol. 199, 1287-1294.

Zar, J.H., 1999. Biostatistical análisis. $4^{\text {th }}$ Edition (Englewood Cliffs, NJ: Prentice-Hall). Pp. 718.

Zurburg, W., and de Zwaan, A., 1981. The role of amino acids in anaerobiosis and osmorregulation in bivalves. J. Exp. Zool. 215, 315-325. 


\section{Legend of Figures}

Figure 1. Relationship between relative taurine concentrations and whole soft tissues dry weight of Mytilus galloprovincialis. Allometric function is drawn in the Figure according to the model $\left(y=a \cdot x^{b}\right)$.

Figure 2. Isometric relationships between gill epithelium (A), labial palps (B) and posterior adductor muscle $(\mathrm{C})$ dry weight variability (mg per individual) with regard to total soft tissue dry weight. Test for isometry (see Material and Methods) were performed on logarithmic transformed relationships and equations are shown in the text. Figure D illustrates percentage values that each of the latter specific tissues represent within total soft tissues with regard to increasing size of individuals.

Figure 3. Allometric relationships between digestive gland (A), foot (B) and mantle (C) dry weight variability (mg per individual) with regard to total soft tissue dry weight. Test for isometry (see Material and Methods) were performed on logarithmic transformed relationships and equations are shown in the text. Figure D illustrates percentage values that each of the latter specific tissues represent within total soft tissues with regard to increasing size of individuals.

Figure 4. Relative amounts of taurine as micromoles per gram of specific tissue with regard to increasing size (soft tissues weight) of individuals. Power functions $y=a \cdot x^{b}$ were used to fit taurine amounts with increasing size of individuals in all cases. Equations and significance values are shown in text and Figure.

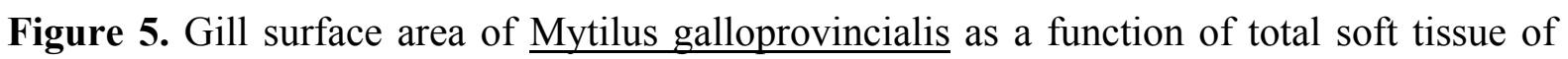
individuals. Power function $\left(\mathrm{Y}=\mathrm{a} \cdot \mathrm{X}^{\mathrm{b}}\right)$ was used to fit gill area values to body size (weight) and equation is shown in the Figure. 


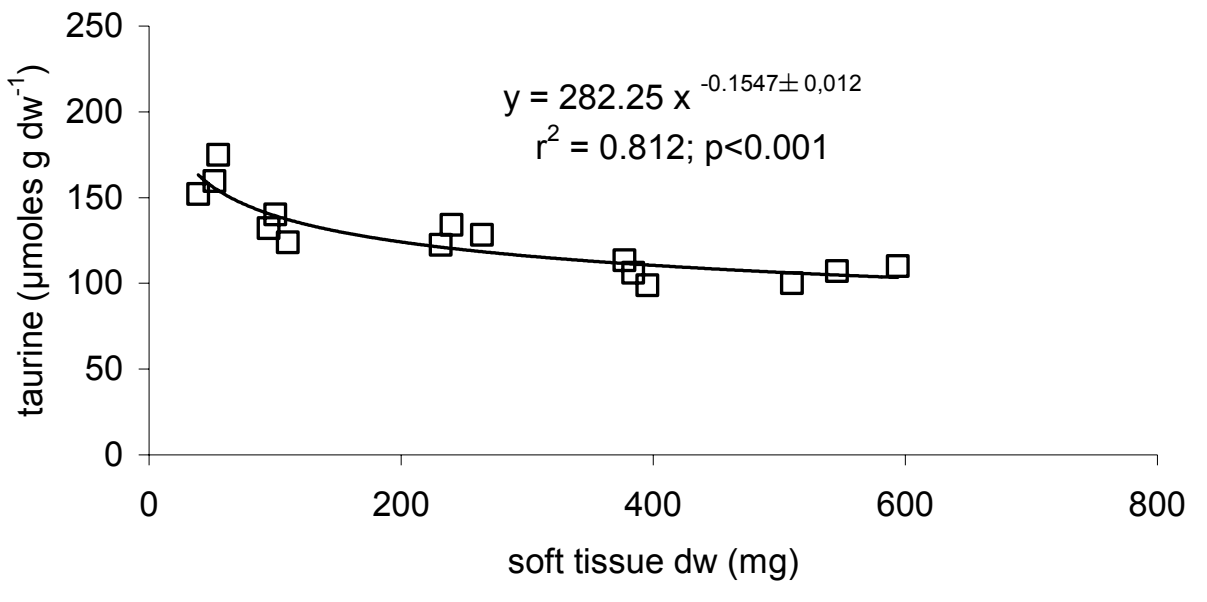

$\begin{array}{lllll}20 & 30 & 40 & 50 & 60 \mathrm{~mm} \text { shell length class }\end{array}$

Figure 1 


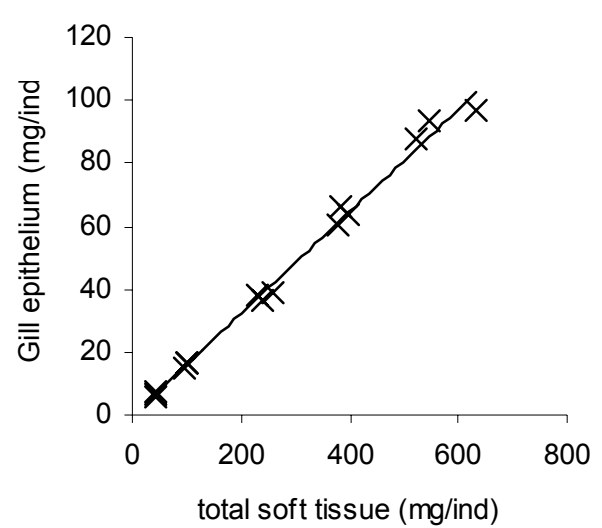

C

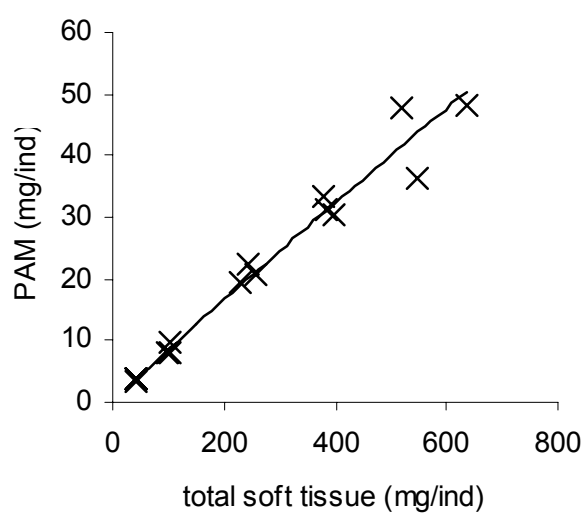

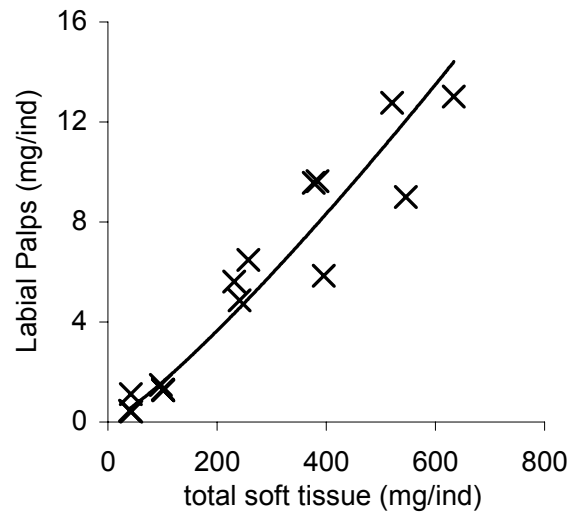

D

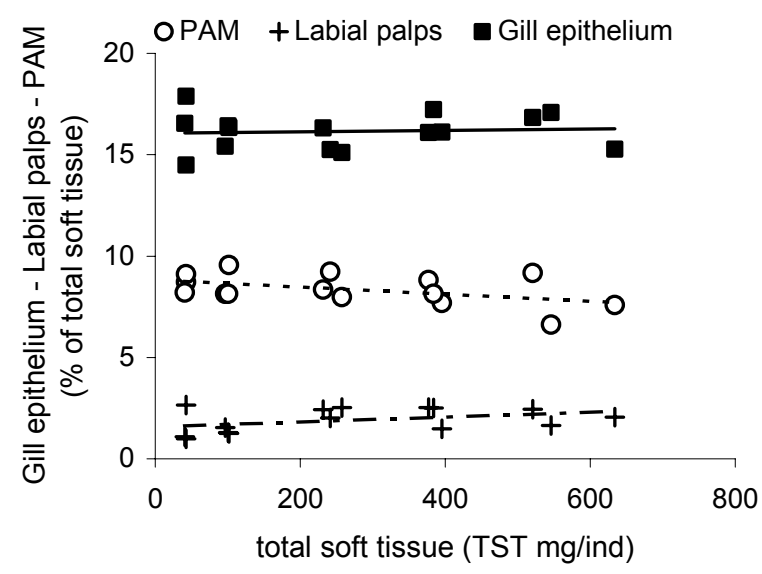

Figure 2 


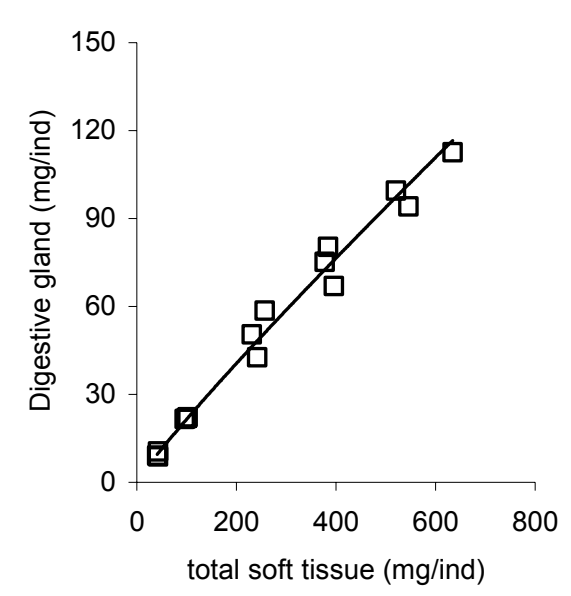

C

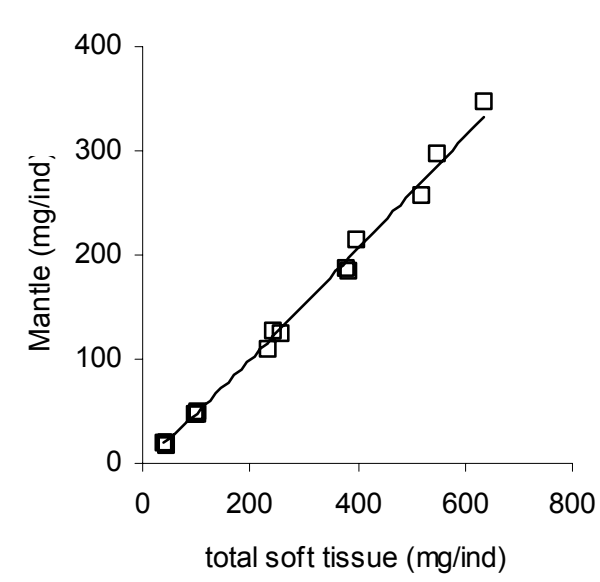

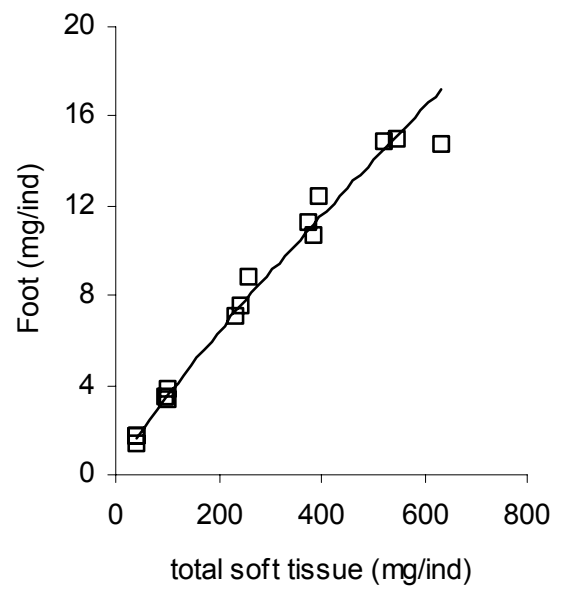

D

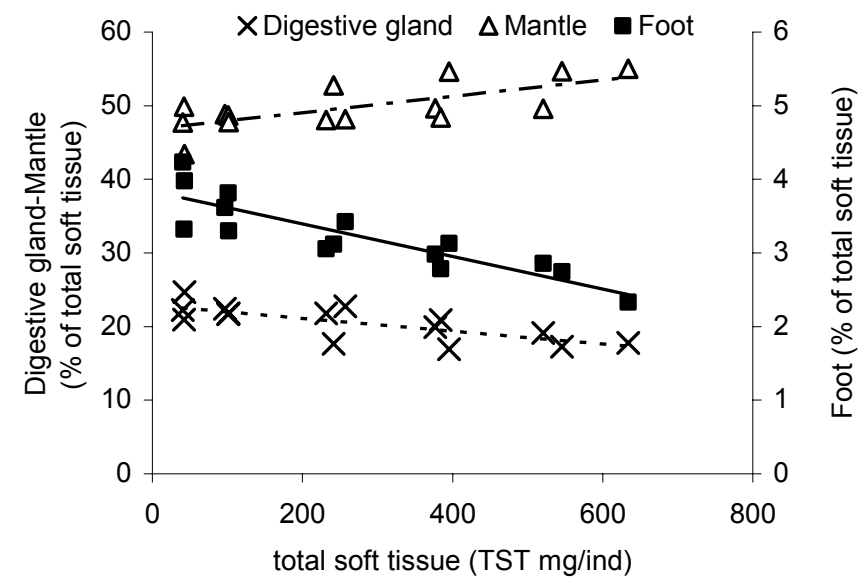

Figure 3 
Gill epithelium

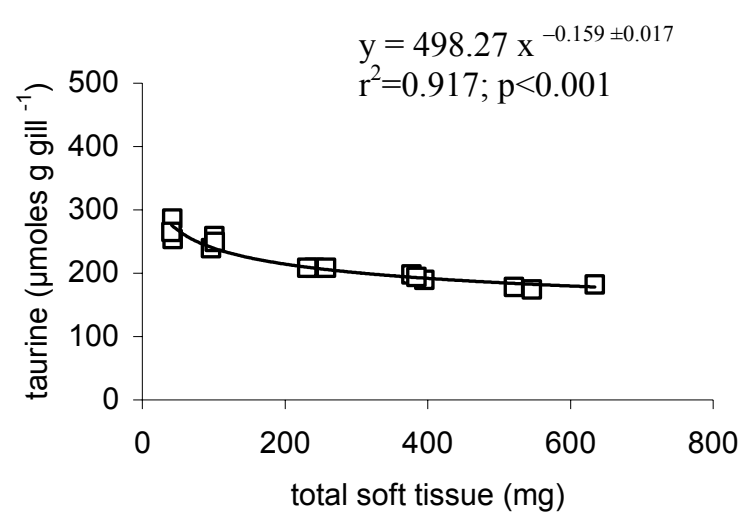

PAM

C

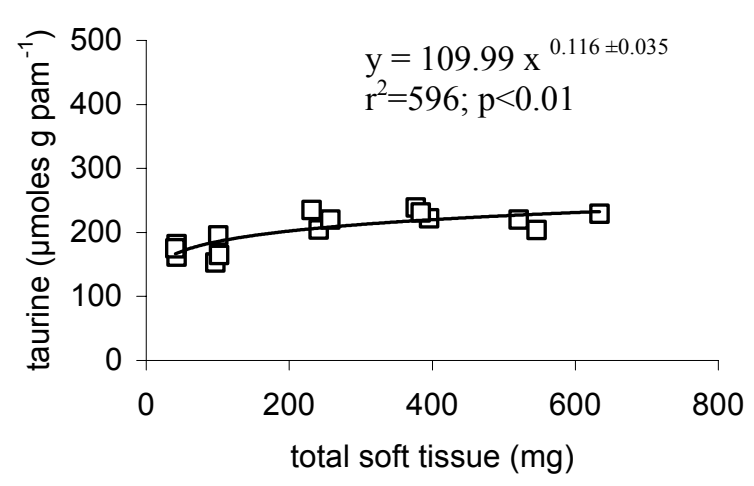

Digestive gland

E

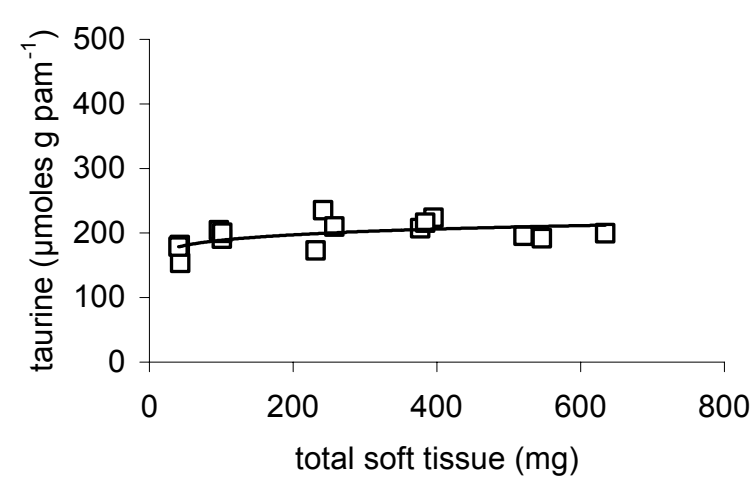

A
Labial palps B

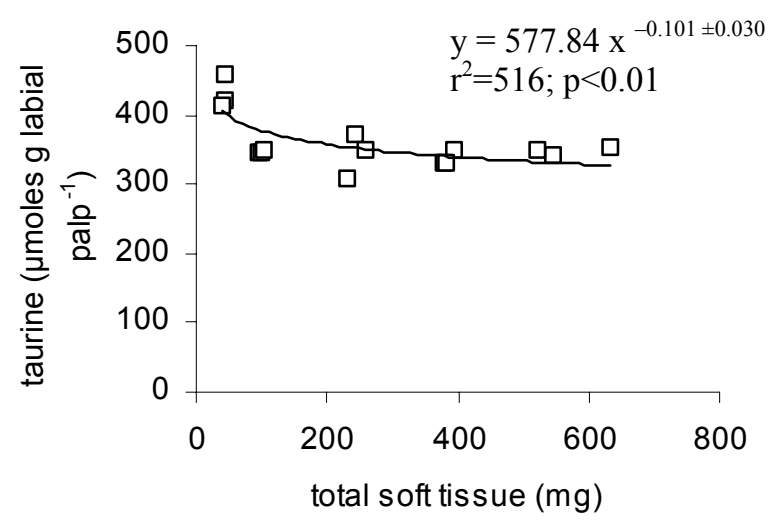

Mantle

D

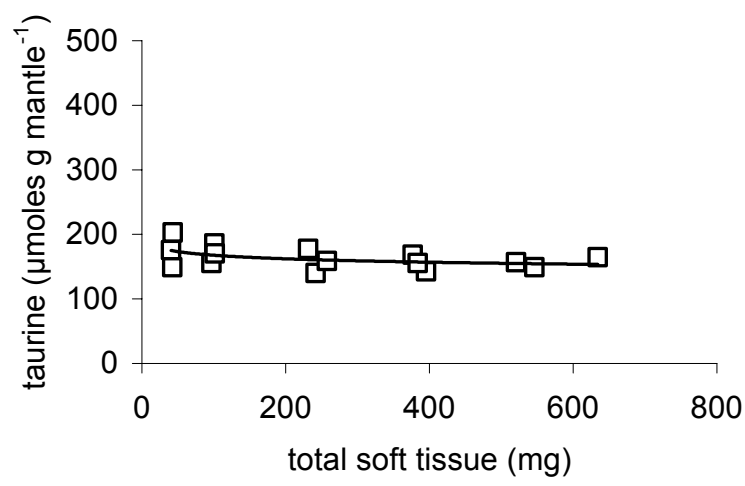

Foot

F

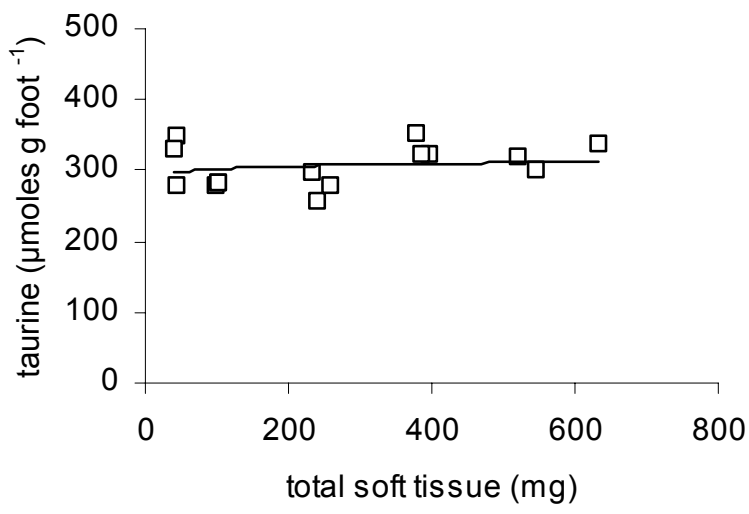

Figure 4 


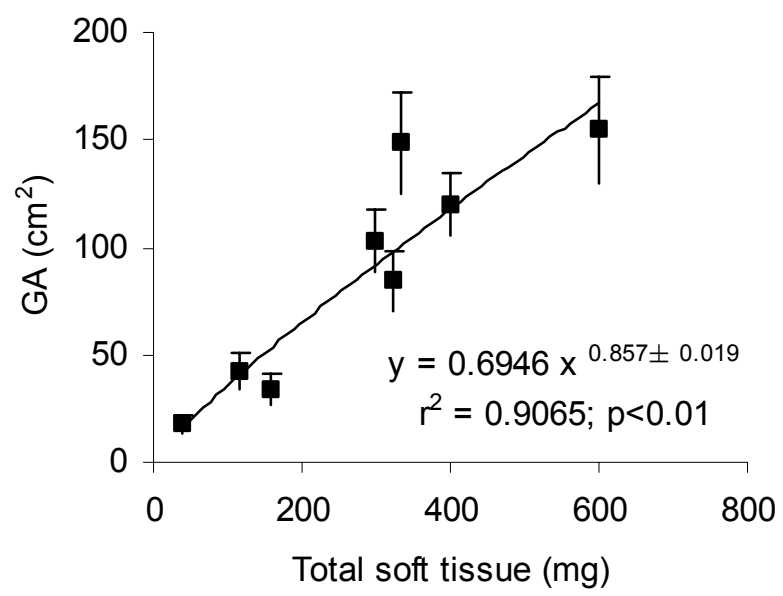

Figure 5 